\title{
Rapid formation of isoprene photo-oxidation products observed in Amazonia
}

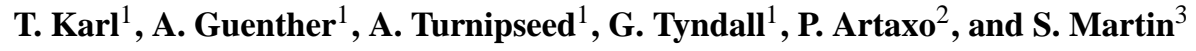 \\ ${ }^{1}$ National Center for Atmospheric Research, 1850 Table Mesa Dr, Boulder, 80301, CO, USA \\ ${ }^{2}$ Instituto de Fisica, Universidade de Sao Paulo, Sao Paulo, Brazil \\ ${ }^{3}$ School of Engineering and Applied Sciences \& Department of Earth and Planetary Sciences, Harvard University, \\ Cambridge, MA, USA
}

Received: 20 May 2009 - Published in Atmos. Chem. Phys. Discuss.: 22 June 2009

Revised: 26 August 2009 - Accepted: 28 September 2009 - Published: 19 October 2009

\begin{abstract}
Isoprene represents the single most important reactive hydrocarbon for atmospheric chemistry in the tropical atmosphere. It plays a central role in global and regional atmospheric chemistry and possible climate feedbacks. Photooxidation of primary hydrocarbons (e.g. isoprene) leads to the formation of oxygenated VOCs (OVOCs). The evolution of these intermediates affects the oxidative capacity of the atmosphere (by reacting with $\mathrm{OH}$ ) and can contribute to secondary aerosol formation, a poorly understood process. An accurate and quantitative understanding of VOC oxidation processes is needed for model simulations of regional air quality and global climate. Based on field measurements conducted during the Amazonian Aerosol Characterization Experiment (AMAZE-08) we show that the production of certain OVOCs (e.g. hydroxyacetone) from isoprene photooxidation in the lower atmosphere is significantly underpredicted by standard chemistry schemes. Recently reported fast secondary production could explain $50 \%$ of the observed discrepancy with the remaining part possibly produced via a novel primary production channel, which has been proposed theoretically. The observations of OVOCs are also used to test a recently proposed $\mathrm{HO}_{\mathrm{x}}$ recycling mechanism via degradation of isoprene peroxy radicals. If generalized our observations suggest that prompt photochemical formation of OVOCs and other uncertainties in VOC oxidation schemes could result in uncertainties of modelled $\mathrm{OH}$ reactivity, potentially explaining a fraction of the missing $\mathrm{OH}$ sink over forests which has previously been largely attributed to a missing source of primary biogenic VOCs.
\end{abstract}

Correspondence to: T. Karl

(tomkarl@ucar.edu)

\section{Introduction}

Volatile organic compounds (VOCs) critically influence the composition of the Earth's atmosphere by fueling tropospheric chemistry (Atkinson, 2000), and providing condensable oxidation products for organic aerosol formation (Kanakidou et al., 2005). On a global scale the emission strength of biogenic VOCs dominates the annual VOC budget $(\sim 1000-2000 \mathrm{Tg} / \mathrm{y})$. A large fraction of this reduced carbon flux enters the atmosphere in form of isoprene, which could exceed global methane emissions (Guenther et al., 2006). VOCs are emitted from many terrestrial plants at high rates, in particular in tropical ecoregions, and some species are known to re-emit up to $10 \%$ of their assimilated carbon in form of isoprene (Kesselmeier et al., 2002). Isoprene is also highly reactive and its photochemical evolution therefore plays a central role in atmospheric chemistry.

Detailed chemical schemes are needed in global atmospheric chemistry models (e.g. Brasseur et al., 1998; Bey et al., 2001; Kuhlmann et al., 2003) to simulate the tropical photo-reactor and assess how the oxidizing capacity of the remote tropical atmosphere is modulated by this compound. Isoprene chemistry schemes (Fan and Zhang, 2004; Carter and Atkinson, 1996; Pinho et al., 2005) are typically condensed so they can be incorporated in global and regional chemistry models. Most current lumped chemistry schemes include near explicit representation of the first and second generation oxidation products of isoprene (Emmons et al., 2009; Taraborelli et al., 2008; Emmerson and Evans, 2009). Some of these schemes have been applied in field studies conducted in the tropics (e.g. Warneke et al., 2001; Ganzeveld et al., 2008). Recent theoretical and laboratory evidence suggested that some of the basic steps of isoprene

Published by Copernicus Publications on behalf of the European Geosciences Union. 
peroxy radical cycling are still poorly understood (Dibble, 2004; Park et al., 2003; Peeters et al., 2009; Paulot et al., 2009a) and ramifications for $\mathrm{HO}_{\mathrm{x}}$ cycling have been discussed (Lelieveld et al., 2008; Hofzumahaus et al., 2009; Paulot et al., 2009a). Here we use field measurements of isoprene and its oxidation products methyl vinyl ketone (MVK), methacrolein (MAC) and hydroxyacetone to assess their photochemical evolution and test existing kinetic schemes at a remote field site approx. $60 \mathrm{~km}$ NNW of Manaus in the central Amazon basin during the wet season in 2008.

\section{Methods}

\subsection{Measurement site}

Measurements were conducted as part of the Amazonian Aerosol Characterization Experiment (AMAZE-08) from 9 to 28 February 2008 . The site $\left(02^{\circ} 35.657^{\prime} \mathrm{S}, 60^{\circ} 12.557^{\prime} \mathrm{W}\right)$ located in the Reserva Biologica do Cuieiras and managed by the Instituto Nacional de Pesquisas da Amazonia (INPA) and the Large-Scale Biosphere-Atmosphere Experiment in Amazonia (LBA). The vegetation cover consists of primary tropical rainforest (approx. leaf area index of $5-6 \mathrm{~m}^{2} / \mathrm{m}^{2}$ ) with an average canopy height of $\sim 30 \mathrm{~m}$ surrounding the $\sim 40 \mathrm{~m}$ measurement tower.

\subsection{VOC measurement and data analysis}

A Proton-Transfer-Reaction Mass Spectrometer was used for gradient measurements of selected VOCs. The instrument is based on soft chemical ionization using protonated water ions $\left(\mathrm{H}_{3} \mathrm{O}^{+}\right)$. It combines the advantage of online analysis while maintaining linearity and low detection limits (Ionicon, Austria) (Lindinger et al. 1998; Hansel et al., 1998). The instrument was operated at 2.3 mbar drift pressure and $540 \mathrm{~V}$ drift voltage and calibrated using two multicomponent ppmv VOC standards: VOC standard 1 contained a mixture of methanol, acetonitrile, acetaldehyde, acetone, isoprene, methyl vinyl ketone, methyl ethyl ketone, benzene, toluene, m,o,p xylenes and camphene; VOC standard 2 contained a mixture of benzene, toluene, m,o,p xylenes + ethylbenzene, chlorobenzene, trimethylbenzenes, dichlorobenzenes and trichlorobenzenes. Ultrapure hydroxyacetone (SigmaUltra, Sigma Aldrich, CAS 116-09-6, Milwaukee, WI) was injected into the instrument to determine the instrument specific response for this compound. The instrument sequentially sampled of six independent $\frac{1}{4}^{\prime \prime}$ inch Teflon (PFA) sampling lines mounted at 2, 10.9, 16.7, 23.9, 30.3 , and $39.8 \mathrm{~m}$ on the tower. A valve switching system changed sampling lines every $5 \mathrm{~min}$ and cycled through the entire gradient over a $30 \mathrm{~min}$ period. Gradients were calculated from the $5 \mathrm{~min}$ averages. High flow rates through the sampling lines resulted in delay times of less than $8-12 \mathrm{~s}$, measured by spiking a VOC pulse at each sampling inlet.
Isoprene and the sum of MVK and MAC were measured at ion channels $m / z, 69$ and $m / z, 71$ respectively. The specificity of the PTRMS to monitor isoprene and the sum of MVK+MAC has been demonstrated previously (e.g. de Gouw and Warneke, 2007). Hydroxyacetone was monitored on ion channel $\mathrm{m} / \mathrm{z} 75$ and was identified as a major VOC observed by PTRMS in tropical ecosystems in the past (Williams et al., 2001). The detection limits for isoprene, MVK+MAC and hydroxyacetone for a $5 \mathrm{~s}$ integration time were 10, 5 and 5 pptv respectively. Particular sensitivities corresponded to proton-transfer reaction rate constants of $2 \mathrm{e}-9,3 \mathrm{e}-9$ and $3.5 \mathrm{e}-9 \mathrm{~cm}^{3} / \mathrm{s}$ respectively. PTRMS hydroxyacetone concentration data from earlier field campaigns (Williams et al., 2001; Holzinger et al., 2007; Stroud et al., 2005) were corrected by the relative difference of the rate constants between hydroxyacetone and isoprene. Potential interferences on $\mathrm{m} / \mathrm{z} 75$ due to butanol can be excluded as butanol completely dehydrates and is observed exclusively on $\mathrm{m} / z .57$ under operating conditions used here. Propionic acid also dehydrates partially into $\mathrm{m} / z$ 57. Our dataset shows no significant correlation between signals observed on $m / z 57$ and $m / z$ 75, which is indicative that propionic acid did not contribute to $\mathrm{m} / \mathrm{z} 75$. The most likely candidate for $\mathrm{m} / \mathrm{z} 75$ is therefore a compound originating from isoprene oxidation. We can further exclude other interferences such as diethylether and methyl acetate from GC samples. We conclude that the PTRMS mass channel $\mathrm{m} / \mathrm{z} 75$ was specific for the measurement of hydroxyacetone in this high isoprene environment and confirm conclusions drawn from earlier studies (Williams et al., 2001).

GC-MS air samples were collected on carbotrap and tenax cartridges that were stored at approximately $0^{\circ} \mathrm{C}$ until analysis at NCAR Boulder laboratory, except during transit from Brazil to USA, when they were at ambient temperature for approximately 1 day. The cartridges were desorbed thermally using an NCAR-made system (Greenberg et al., 1994) and analyzed by gas chromatography with mass spectrometric detection (Hapsite Smart, Inficon, East Syracuse NY) using a $30 \mathrm{~m} \times 0.3 \mathrm{~mm}$ ID $1 \mathrm{~mm}$ film DB- 1 column, temperature programmed from 40 to $200^{\circ} \mathrm{C}$ at $3^{\circ} \mathrm{C}$ per min after an initial 2 min hold. VOC were quantified with respect to NIST traceable standards as described by Greenberg et al. (1994).

Ozone $\left(\mathrm{O}_{3}\right)$, and nitric oxide (NO) concentrations were also measured via the 6-level sampling manifold. Ozone was measured by UV absorbance (2B Technologies, Model 205) every $10 \mathrm{~s}$ and then averaged over the entire $5 \mathrm{~min}$ sampling time on each level, excluding only the first $15 \mathrm{~s}$ to insure adequate flushing of the connecting gas lines. The ozone analyzer was compared with laboratory instruments both prior to and following the experiment and found to agree with $\pm 5 \%$ with a detection limit of 2 ppbv. It was zeroed periodically by placing an ozone scrubber on the $1.5 \mathrm{~m}$ inlet. NO was measured by ozone-induced chemiluminescence (Ecophysics, Model 88Y) at a sample rate of $1 \mathrm{~s}$. Measurements were averaged over the first 2 min of sampling 


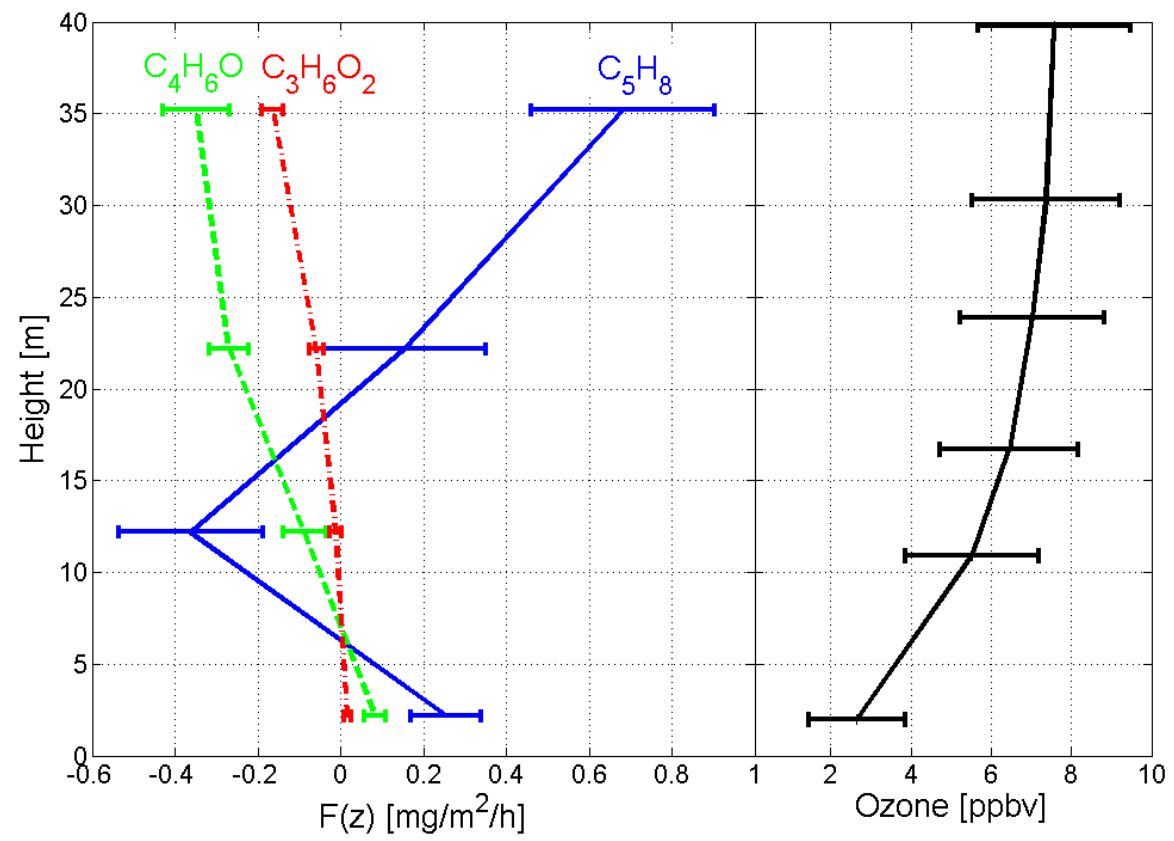

Fig. 1. Integrated flux and concentration profiles through $30 \mathrm{~m}$ canopy. Left panel: Integrated flux profiles of Isoprene $\left(\mathrm{C}_{5} \mathrm{H}_{8}\right), \mathrm{MVK} \mathrm{MAC}$ $\left(\mathrm{C}_{4} \mathrm{H}_{6} \mathrm{O}\right)$ and Hydroxyacetone $\left(\mathrm{C}_{3} \mathrm{H}_{6} \mathrm{O}_{2}\right)$. Right panel: Ozone concentration profile.

on a given level (excluding initial $15 \mathrm{~s}$ ). During the other $3 \mathrm{~min}$, the air was either passed through a photolytic converter (Droplet Technology, BLC-100) to convert $\mathrm{NO}_{2}$ to $\mathrm{NO}$ or through a molybdenum catalyst which reduces oxidized nitrogen to NO which was subsequently detected by chemiluminescence. The NO analyzer was zeroed automatically every hour by diverting the sample flow through a pre-reactor and adding a large excess of ozone which consumed the NO. It was calibrated periodically during the campaign by standard addition of a known NO concentration to the $2 \mathrm{~m}$ inlet. The detection limit was $\sim 50 \mathrm{pptv}$. Laboratory tests indicated no measurable loss of either ozone, $\mathrm{NO}$ or $\mathrm{NO}_{2}$ within any of the PFA inlet lines. Wind velocities at $40 \mathrm{~m}$ were measured by a 3-dimensional sonic anemometer (Applied Technologies, SATI-K) mounted on a boom extending $2 \mathrm{~m}$ from the tower and sampled at $20 \mathrm{~Hz}$.

\subsection{VOC gradient fluxes}

Ecosystemscale fluxes of VOCs were calculated based on concentration gradients throughout the canopy and applying an Inverse Lagrangian Transport Model (Raupach, 1989, Nemitz et al., 2000, and Karl et al., 2004). The VOC fluxes were computed according to $\overrightarrow{\boldsymbol{C}}-\boldsymbol{C}_{\text {ref }}=\stackrel{\leftrightarrow}{\mathrm{D}} \cdot \overrightarrow{\boldsymbol{S}}$, where $\boldsymbol{C}$ is the VOC concentration $\left(\mu \mathrm{g} / \mathrm{m}^{3}\right)$ vector for each level, $\boldsymbol{C}_{\text {ref }}$ is the VOC concentration $\left(\mu \mathrm{g} / \mathrm{m}^{3}\right)$ at reference height (e.g. $\left.14 \mathrm{~m}\right)$, D (m) represents a dispersion matrix and $S\left(\mathrm{mg} / \mathrm{m}^{2} / \mathrm{h} / \mathrm{m}\right)$ the resulting VOC source/sink vector. D can be expressed as a function of Lagrangian timescale ( $\mathrm{Tl}$ ) and profiles of the standard deviation of the vertical wind speed $\left(\sigma_{w}\right)$ divided by the friction velocity $(u *)$. The calculation was performed using a $10 \times 4$ dispersion matrix. Integration over all source and sink terms $(\boldsymbol{S})$ yielded the canopy scale VOC flux $\left(\mathrm{mg} / \mathrm{m}^{2} / \mathrm{h}\right)$. Fluxes were calculated for $30 \mathrm{~min}$ intervals. The parameterization of $\mathbf{D}$ was based on turbulence measurements inside and above the canopy and calculated using the far- and near-field approach described by Raupach (1989). The Lagrangian timescale was parameterized according to Raupach (1989).

\section{Results and discussion}

\subsection{Biosphere-Atmosphere exchange of isoprene, MVK+MAC and Hydroxyacetone}

Figure 1 (left panel) shows the exchange of VOCs at the atmosphere-biosphere interface and depicts the mean integrated vertical source/sink distribution of isoprene, MVK, MAC and hydroxyacetone measured by PTR-MS during daytime (11:00-17:00 local time (LT)). The source/sink distribution was inferred from in-canopy concentration measurements using an inverse Lagrangian transport model. Average midday ozone mixing ratios (Fig. 1, right panel) were $\sim 8 \mathrm{ppbv}$ decreasing to $<3 \mathrm{ppbv}$ near the ground. Isoprene was mostly emitted in the upper part of the canopy as expected because of the light environment and the distribution of sun and shade leaves throughout the canopy. The oxidation products MVK, MAC and hydroxyacetone were 
deposited to the canopy with maximum deposition occurring near the top. The calculated source/sink distribution integrated over the entire canopy for these VOCs suggests that the primary source was located above the forest. The analysis shows that primary biological emissions of MVK, MAC and hydroxyacetone were negligible during this study.

Observed OVOC mixing ratios are determined by the balance of their combined loss and production rates. While their production rates are dominated by photochemistry, their loss rates are influenced by photochemical destruction, dry deposition and vertical mixing (such as entrainment of air from the free troposphere). In order to estimate the relative importance of these three loss terms we assume a $1000 \mathrm{~m}$ deep well-mixed planetary boundary layer (PBL) (Karl et al., 2007). The lifetime due to dry deposition equals the mixed layer concentration times the PBL height divided by the deposition flux (Fig. 1). Taking mixing ratios of 3 and $1.5 \mathrm{ppbv}$ for MVK+MAC and hydroxyacetone, the lifetime due to dry deposition is on the order of 25 and $22 \mathrm{~h}$ respectively. Similarly the influence of entrainment can be estimated. Mixing ratios in the free troposphere (FT) are typically an order of magnitude lower (Karl et al., 2007; Kuhn et al., 2007). The concentration jump of a VOC between the PBL and FT can then be approximated by the mixed layer concentration. For the measured entrainment velocities obtained during an earlier study (e.g. Karl et al., 2007; $8-10 \mathrm{~cm} / \mathrm{s}$ ) the dilution timescale of vertical mixing is $3-4 \mathrm{~h}$.

These physical loss processes can be compared to the chemical destruction rate for a daytime $\mathrm{OH}$ densitiy of $5 \mathrm{e} 6$ molecules $/ \mathrm{cm}^{3}$ (Ganzeveld et al., 2008). The corresponding chemical lifetimes for isoprene, MVK+MAC and hydroxyacetone are $0.5,2$ and $18 \mathrm{~h}$ respectively. Since daytime concentrations of isoprene, MVK, MAC and hydroxyacetone in the FT are typically much lower than in the PBL the effect of vertical dilution has minimal influence on VOC correlations observed in the PBL, because all VOCs are diluted at the similar rates. When investigating correlations of OVOCs (e.g. MVK and MAC) with respect to isoprene, the additional sink due to OVOC dry deposition would result in systematically lower OVOC mixing ratios than would be calculated from photochemical destruction alone.

\subsection{Photochemical production of MVK, MAC and hydroxyacetone}

The first steps of the photo oxidation of isoprene via the hydroxyl radical $(\mathrm{OH})$ can be summarized as:

$$
\begin{aligned}
& \mathrm{C}_{5} \mathrm{H}_{8}+\mathrm{OH} \stackrel{\mathrm{O} 2}{\longrightarrow} \mathrm{C}_{5} \mathrm{H}_{9} \mathrm{O}_{3} \\
& \mathrm{C}_{5} \mathrm{H}_{9} \mathrm{O}_{3}+\mathrm{NO} \longrightarrow \text { carbonyls } \\
& \mathrm{C}_{5} \mathrm{H}_{9} \mathrm{O}_{3}+\mathrm{HO}_{2} \longrightarrow \text { peroxides }
\end{aligned}
$$

Measured NO mixing ratios were sufficiently high (100$300 \mathrm{pptv}$, lifetime $\tau$ of $\sim 30 \mathrm{~s}$ ) in the surface layer to dominate over the reaction with $\mathrm{HO}_{2}$ radical estimates (10-20 pptv; $\tau \sim 300 \mathrm{~s}$ ) according to results from a photochemical box model based on the Mozart Chemistry Mechanism v4 (Emmons et al., 2009). Consequently peroxy radical reactions with $\mathrm{NO}(\tau \sim 30 \mathrm{~s})$ led to significant production of the carbonyls methyl vinyl ketone (MVK) and methacrolein (MAC). For VOCs discussed here Reaction (R1) can therefore be simplified to the following kinetic reaction model, where $\mathrm{Y}$ is the branching ratio for each channel.

$$
\begin{aligned}
& \mathrm{C}_{5} \mathrm{H}_{8}+\mathrm{OH} \stackrel{\mathrm{Y}=0.32}{\longrightarrow} \mathrm{MVK} \\
& \mathrm{C}_{5} \mathrm{H}_{8}+\mathrm{OH} \stackrel{\mathrm{Y}=0.32}{\longrightarrow} \mathrm{MAC} \\
& \mathrm{MAC}+\mathrm{OH} \stackrel{\mathrm{Y}=0.42}{\longrightarrow} \text { Hydroxyacetone } \\
& \mathrm{MVK}+\mathrm{OH} \longrightarrow \text { Products }
\end{aligned}
$$

Uncertainties for yields are typically on the order of $20 \%$ (Atkinson et al., 1997). While the focus in this section is on the observed mixing ratios of isoprene, MVK, MAC and hydroxyacetone a more detailed representation of the atmospheric production of OVOCs from isoprene is discussed in Sect. 3.3. During daytime the evolution of isoprene chemistry in the PBL is conceptually different than many environmental chamber experiments in that there is continuous supply of isoprene. As a result the production of compounds originating directly from first generation isoprene peroxy radicals is relatively more prominent in the real atmosphere. For example the ratio of (MVK+MAC)/isoprene will approach infinity in batch-mode environmental chambers, while there is a steady-state upper limit of $\sim 2.4$ in the PBL (assuming yields according to reaction $\mathrm{R} 2$ and $\mathrm{OH}$ reaction rate constants of $1 \mathrm{e}-10 \mathrm{~cm}^{3} / \mathrm{s}, 1.9 \mathrm{e}-11 \mathrm{~cm}^{3} / \mathrm{s}$ and $3.4 \mathrm{e}-$ $11 \mathrm{~cm}^{3} / \mathrm{s}$ for isoprene, MVK and MAC respectively). However, due to the time-dependent isoprene supply and the slower $\mathrm{OH}$ reactions of the products, steady state conditions are rarely reached. During AMAZE-08 a daytime (11:0017:00 LT) ratio of $0.44 \pm 0.05$ was observed (Fig. 2, left panel). Similar ratios were observed in previous field studies (e.g. Warneke et al., 2001; Kuhn et al., 2007; Eerdekens et al., 2008; Karl et al., 2007).

The major source of hydroxyacetone is oxidation of MAC (e.g. Carter and Atkinson, 1996). Figure 2 (right panel) shows a correlation plot between hydroxyacetone and the sum of the first generation oxidation products MVK and MAC. For a given MVK+MAC to isoprene ratio of 0.44 we calculate a slope of 0.03 between hydroxyacetone and MVK+MAC according to Reaction (R2) (assuming constant isoprene emissions). This is $\sim 10$ times smaller than the observed ratio $(0.30 \pm 0.08)$ and implies that an additional source of hydroxyacetone, which is highly correlated with the oxidation products MVK and MAC $\left(R^{2}=0.79\right)$ and isoprene $\left(R^{2}=0.70\right)$, is missing. The high degree of correlation suggests that the missing source of hydroxyacetone comes 


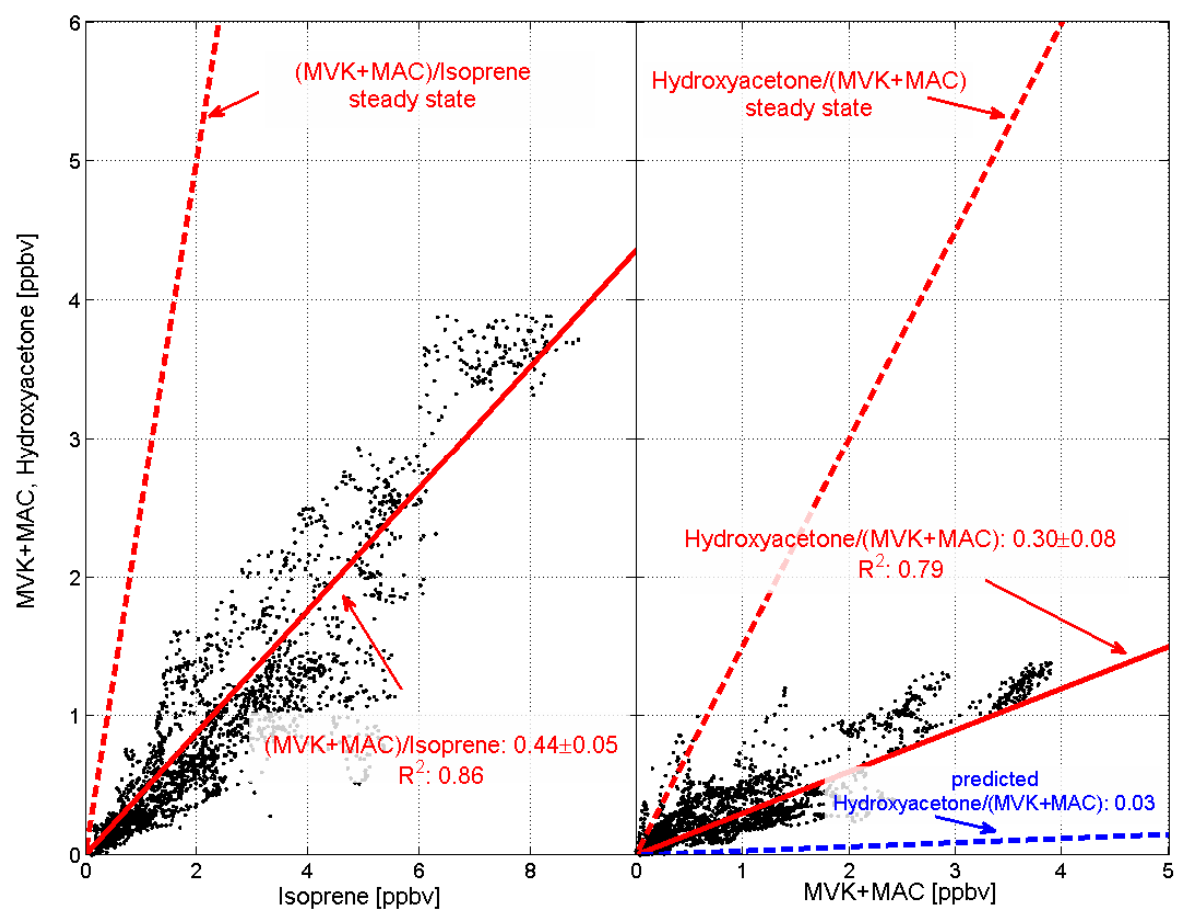

Fig. 2. Left panel: Correlation between MVK+MAC and isoprene. Right panel: Correlation between hydroxyacetone and MVK+MAC. Regressions based on a robust fitting procedure are indicated by solid red lines (Holland et al., 1977). The dashed red lines indicate steady state limits. The modelled hydroxyacetone/(MVK+MAC) slope is depicted by the blue dashed line.

from within the isoprene oxidation chain, but has to be faster than the production from MAC, which is thought to be the major contributor to the secondary formation of hydroxyacetone. Other possible chemical sources of hydroxyacetone include oxidation of peroxides originating from propene and production from acetone oxidation (e.g. acetonyl peroxy radicals reacting with methyl peroxy radicals). However, both of these are expected to be slow due to the low concentrations of propene and subsequent peroxides or the need for radicalradical reactions in the case of acetone oxidation. Since isoprene mixing ratios (e.g. up to $8 \mathrm{ppbv}$ ) dominate the tropical environment these processes must compete with the dominant production path via MAC. Although anticipated to be small in the wet season of the central Amazon Basin, another possible source of hydroxyacetone is biomass burning (Yokelson et al., 2007). We investigated this using acetonitrile as specific gas phase marker. Periods of elevated acetonitrile ( $\sim 10 \%$ of the entire dataset) were excluded from the analysis. A further argument against a significant biomass burning source is the good correlation observed between hydroxyacetone and MVK+MAC as well as with isoprene.

In order to check whether the observed ratios between isoprene, MVK+MAC and hydroxyacetone are comparable to previous datasets we have re-analyzed data reported in the literature. The triangular plot shown in Fig. 3 summarizes findings from five field campaigns, including the present study, conducted near isoprene emission sources (Williams et al.,
2001; Holzinger et al., 2007; Stroud et al., 2005; Spaulding et al., 2003). Concentrations from these datasets, which are representative for typical local noontime conditions, were normalized by the sum of isoprene, MVK, MAC and hydroxyacetone in order to quantitatively compare their relative ratios. The color coded triangular symbols represent a chemical trajectory along which the relative ratios would evolve according to Reaction (R2). The color coding indicates photochemical age (time exposure to $\mathrm{OH}$ ). Due to a constant supply of isoprene the theoretical trajectory ends at the steady state limit, typically reached after $10^{7}$ molecules $\mathrm{cm}^{-3}$ days of $\mathrm{OH}$ exposure for the reaction sequence discussed here. Measured distributions from all field observations, in particular the AMAZE-08 dataset discussed here, show that hydroxyacetone mixing ratios are significantly higher than what would be expected from the reaction model described by Reaction (R2) when only production from MAC is assumed. The discrepancy becomes larger for data collected closer to the source corresponding to a recent supply of isoprene.

Reconciliation with such fast production of hydroxyacetone requires additional production paths from isoprene (e.g. through isoprene alkenoxy radicals). We extended the set of reactions listed in Reaction (R2) by including direct production from isoprene plus $\mathrm{OH}$ and obtained an optimal yield (Yiso) based on a non-linear least square regression procedure (Seber et al., 1989) of the coupled set of differential reactions (R2). The color coded circles in Fig. 3 depicts 


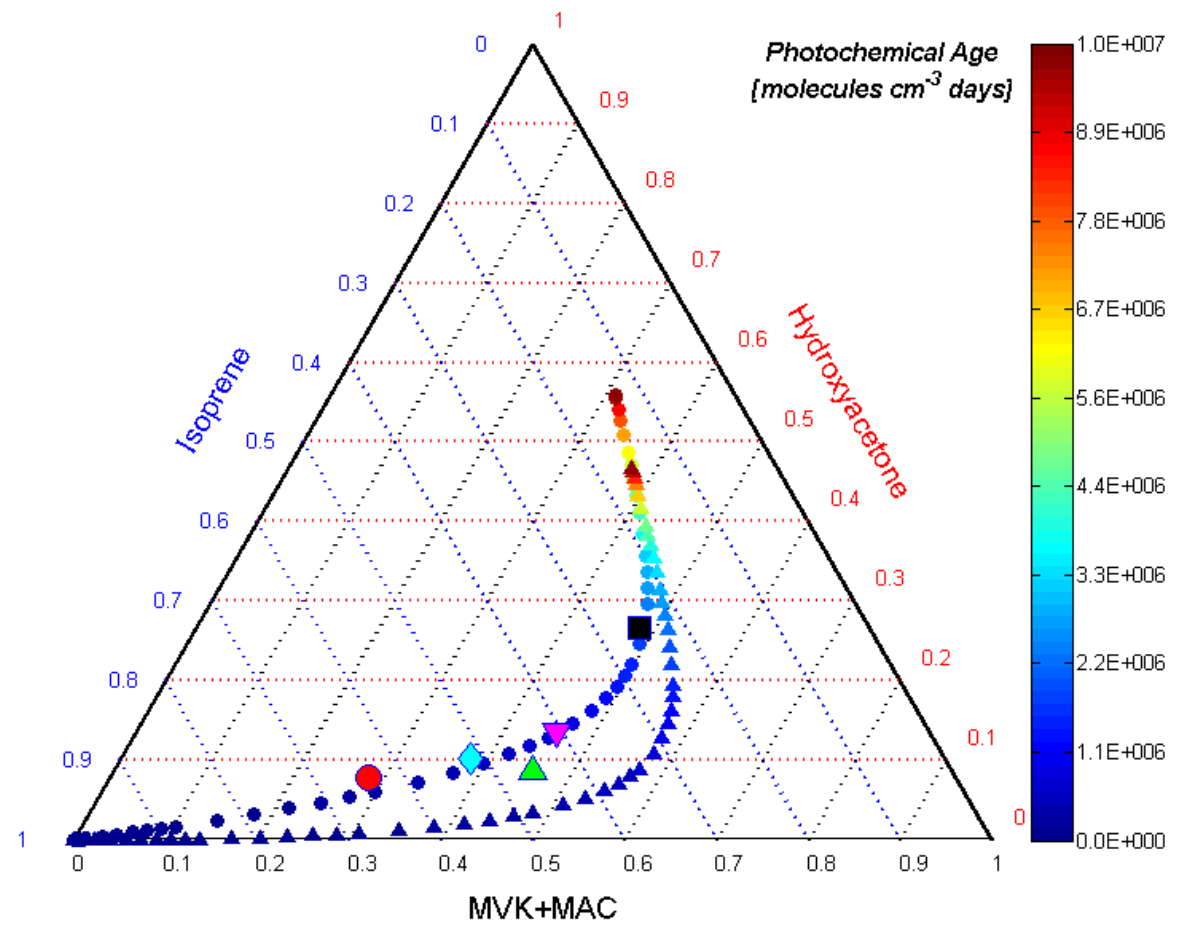

Fig. 3. Triangular correlation plot for the measured and modelled mixing ratios of isoprene, MVK+MAC and hydroxyacetone. Mixing ratios are normalized by the sum of the concentrations of isoprene, MVK, MAC and hydroxyacetone. Modelled concentrations are color coded by photochemical age. Field datasets are depicted by symbols as following: red circle (AMAZE, 2008; this study), blue diamond (LBA-Claire, 1999; Williams et al., 2001), green triangle (CELTIC 2003; Stroud et al., 2005), magenta triangle (ICARTT, 2004; Holzinger et al., 2007) and black square (Blodgett Forest, 2003; Spaulding et al., 2003). Triangles represent the standard model (i.e. no fast production). Circles show the model case that includes fast production based on non-linear regression. The chemical trajectories of the models terminate at the steady state limit, typically reached after $10^{7}$ molecules $\mathrm{cm}^{-3}$ days of $\mathrm{OH}$ exposure.

a curve based on direct production with a fitted Yiso of 8.3 $( \pm 2.2) \%$, which would be sufficient to explain the observed distribution of hydroxyacetone in isoprene dominated environments. Several studies have proposed primary (Dibble et al., 2004) and fast secondary production of hydroxyacetone (Paulot et al., 2009b). Dibble et al. (2004) recently conducted a theoretical study on the decomposition of certain isoprene - alkenoxy radicals and hypothesized a direct channel which would lead to the formation of products typically associated with secondary and tertiary chemistry (e.g. hydroxyacetone and glyoxal). Paulot et al. (2009b) reported very fast production of hydroxyacetone from isoprene nitrates and hydroxycarbonyls after initial reaction with $\mathrm{OH}$.

In order to investigate the sensitivity of the proposed additional production paths for hydroxyacetone, we compared four reaction mechanisms. We implemented (1) the Mozart mechanism (Emmons et al., 2009), (2) a recently developed isoprene oxidation scheme proposed by Paulot et al. (2009b), which was extended for low $\mathrm{NO}_{\mathrm{x}}$ conditions (Paulot et al., 2009a), (3) a simple sequential reaction model (SRM) summarized in Table 2 (Appendix), which was extended to include fast production of hydroxyacetone, and (4) a novel reaction mechanism for isoprene proposed by Peeters et al. (2009) (Table 3, Appendix). Figure 4 shows the results for these model runs, for the conditions encountered during the AMAZE-08 study (viz. constant isoprene emissions and NO mixing ratios of 100 pptv). The top panel in Fig. 4 shows the evolution of the ratio of MVK+MAC to isoprene. Observations during AMAZE-08 (Fig. 2) correspond to a ratio of 0.44, which is shown on the left side of Fig. 4.

The SRM, Mozart and Paulot mechanisms yield systematically higher ratios than does the Peeters mechanism. In order to further investigate the reason for this discrepancy we show the MVK to MAC ratios in the middle panel of Fig. 4. During AMAZE-08, GC-MS measurements suggested a ratio of $1.34 \pm 0.10$ which is similar to earlier studies in the Amazon (Kuhn et al., 2007) and comparable to other isoprene dominated environments (Apel et al., 2002; Stroud et al., 2001). The SRM, Mozart und Paulot mechanisms reproduce the observed MVK/MAC ratios well. The mechanism by Peeters et al. (2009), would predict a ratio of $\sim 10$ for an observed (MVK+MAC) to isoprene ratio of 0.44 (see red vertical line in Fig. 4). Possible reasons for such a large discrepancy are explored in the next section.

The modelled and observed hydroxyacetone to (MVK+MAC) ratios are plotted in the lower panel of 


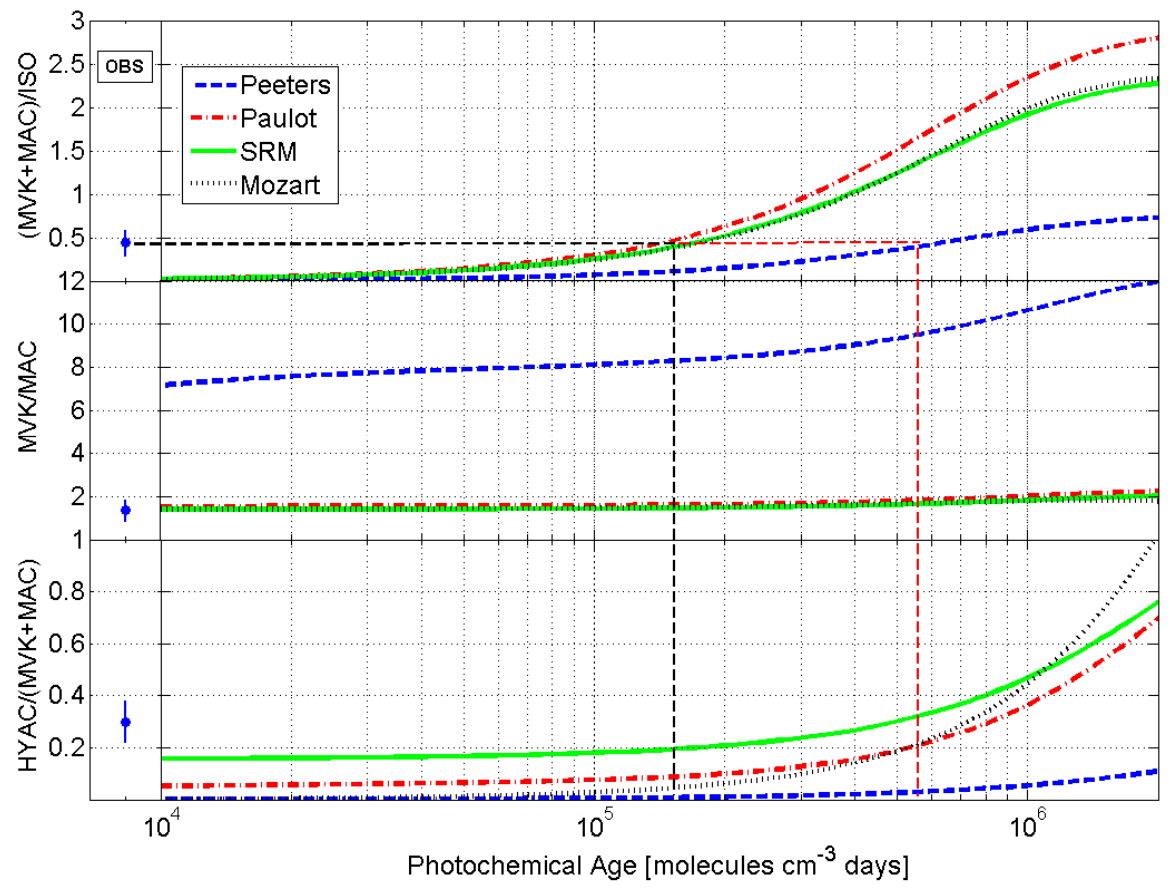

Fig. 4. Observed (left edge) and modelled (main figure) ratios of OVOC to isoprene for four different models (Peeters et al., 2009; Paulot et al., 2009a and b; SRM, a sequential reaction model according to Table A2; Mozart, Emmons et al., 2009). Top: MVK+MAC/isoprene. Middle: MVK/MAC. Bottom: Hydroxyacetone/(MVK+MAC). The dashed black horizontal line corresponds to the (MVK+MAC)/isoprene ratio of 0.44 measured during AMAZE-08, and the dashed black vertical line shows the value of the corresponding photochemical age obtained by the predictions from three models (Paulot, SRM, Mozart). The vertical red line corresponds to the photochemical age by the mechanism of Peeters et al. (2009).

Fig. 4. For a given (MVK+MAC) to isoprene ratio of 0.44 (e.g. vertical black line), the modelled hydroxyacetone to (MVK+MAC) ratio obtained from the Paulot mechanism is closest to the observed ratio (e.g. within 50\%), which was used to derive the modelled SRM curve. This suggests that fast secondary production of hydroxyactone could explain about $50 \%$ of the observed hydroxacetone to (MVK+MAC) ratio during AMAZE-08. The remaining 50\% could be related to primary production mechanisms similar to those proposed by Dibble et al. (2004).

\subsection{Implications for atmospheric chemistry}

\subsection{1 $\mathrm{HO}_{\mathrm{x}}$ recycling}

In the last section OVOC ratios were compared to different photochemical oxidation mechanism. While three of these oxidation schemes could reproduce the observed MVK and MAC mixing ratios, the mechanism presented by Peeters et al. (2009) suffered from unrealistically high MVK/MAC ratios and underestimated the sum of MVK and MAC relative to isoprene. This mechanism is proposed as a novel $\mathrm{HO}_{\mathrm{x}}$ recycling scheme which could potentially explain large missing $\mathrm{HO}_{\mathrm{x}}$ sources in isoprene dominated environments reported by Lelieveld et al. (2008) and Hofzumahaus et al. (2009). The mechanism is summarized in the Table 3 in the Appendix.

Briefly, after initial addition of $\mathrm{OH}$ to one of the four unsaturated $\mathrm{C}$-atoms of isoprene, $\mathrm{O}_{2}$ addition leads to the formation of three isoprene peroxyradicals, which are considered in thermodynamic equilibrium. The two major adducts (1$\mathrm{OH}$-isoprene and 4-OH-isoprene) account for $90 \%$ of the isoprene oxidation channels and are considered here. The Z-1$\mathrm{OH}-4-\mathrm{OO} *$ and Z-4-OH-1-OO* peroxyradicals are proposed to undergo a fast $1,6-\mathrm{H}$-shift $\left(\mathrm{HO}_{2}\right.$ regenerating channels) that competes with conventional reaction channels through $\mathrm{HO}_{2}, \mathrm{RO}_{2}$ and NO. Similarly, the 1-OH-2-OO* and 4-OH-3OO* peroxyradicals would undergo a $1,5-\mathrm{H}$-shift $(\mathrm{OH}$ regenerating channels) competing with reaction via $\mathrm{HO}_{2}, \mathrm{RO}_{2}$ and NO. These proposed radicals would then decompose in a single concerted reaction to generate $\mathrm{HO}_{2}, \mathrm{OH}$, a hydroperoxymethylbutenal, MVK and MAC. The decomposition rates for the 1,6-H-shift reactions are highly dependent on energy barriers and are proposed to be on the order of $1 \mathrm{~s}^{-1}$ and $8 \mathrm{~s}^{-1}$. For comparison the reaction rates via the conventional NO channel would correspond to $0.01-0.03 \mathrm{~s}^{-1}$ for conditions of AMAZE-08. Thus one reason for the different MVK, MAC and hydroxyacetone ratios discussed earlier can be found in these fast decomposition rates. 


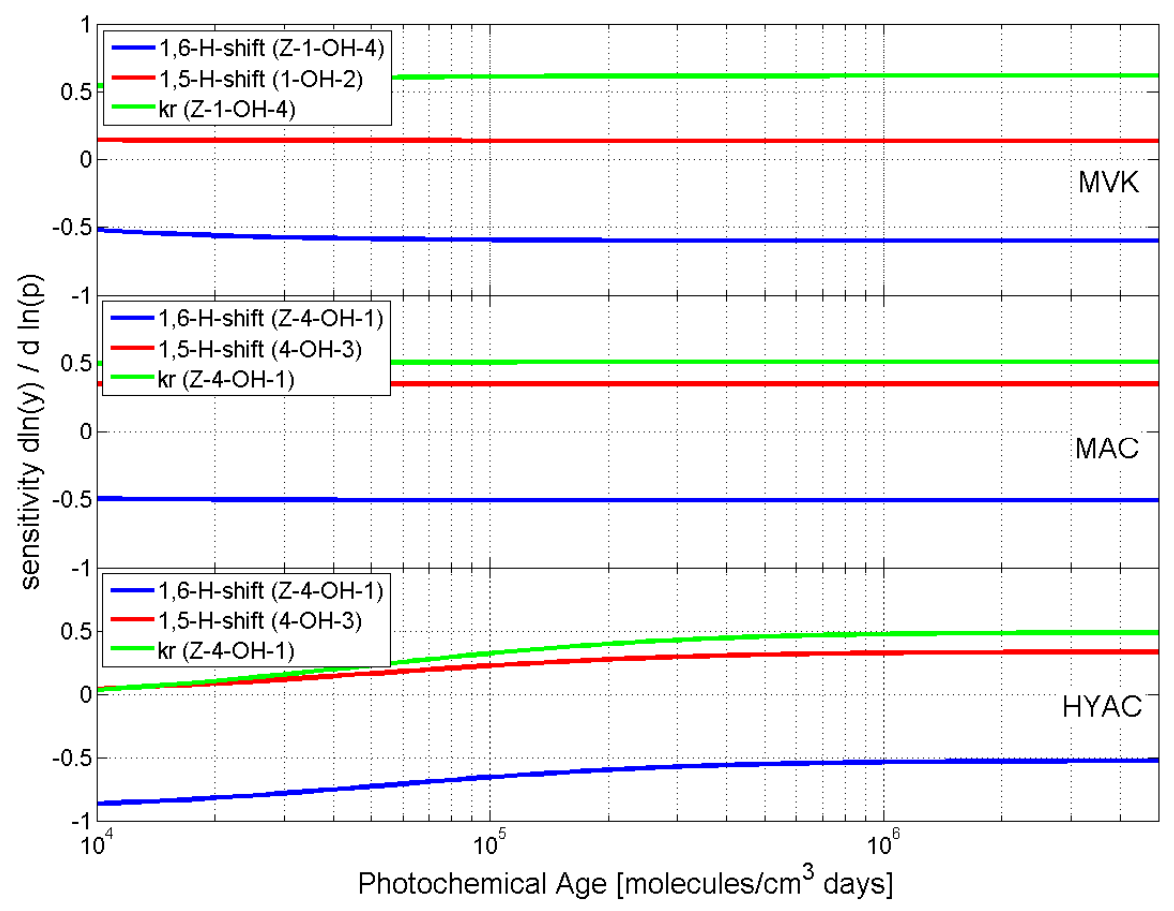

Fig. 5. Analysis of the sensitivity of the OVOCs for increasing photochemical age for the mechanism of Peeters et al. (2009). Top: MVK. Middle: MAC. Lower: Hydroxyacetone. The sensitivity $(\mathrm{d} \ln (\mathrm{u}) / \mathrm{d} \ln (\mathrm{p})$ : change of variable $u$ (e.g. concentration) vs change of parameter $p$ (e.g. rate constant)) of each OVOC is shown with respect to three specific reaction rates of the mechanism (see Table A3).

Figure 5 shows the sensitivity of MVK, MAC and hydroxyacetone with respect to the 1,5- $\mathrm{H}$-shift, 1,6-H-shift and reverse reaction rates of the $\mathrm{Z}-1-\mathrm{OH}-4-\mathrm{OO} *$ and $\mathrm{Z}-4-\mathrm{OH}-1-$ OO* peroxyradicals. For example, a change in the reverse reaction rate $(\mathrm{kr}(\mathrm{Z}-1-\mathrm{OH}-4)$ - green dashed line in upper panel) of $100 \%$ leads to a change in the MVK concentration of $62 \%$ in steady state (e.g. $>1 \mathrm{e} 5$ molecules $\mathrm{cm}^{-3}$ days). Similarly, a change of the rate constant of the 1,6-H-shift of the Z-1-OH-4 reaction (blue line) by $100 \%$ shifts the MVK concentration by $-59 \%$. By changing the rate of the $1,6-$ $\mathrm{H}$-shift for the Z-4-OH-1-peroxy radical by a factor of 10 (e.g. $0.8 \mathrm{~s}^{-1}$ vs $8 \mathrm{~s}^{-1}$ ), the MAC concentration would increase by a factor of 5 and the hydroxyacetone concentration would increase between a factor of 8 at low photochemical age ( $<5 \mathrm{e} 4$ molecules $\mathrm{cm}^{-3}$ days) and 5 at high photochemical age ( $>1 \mathrm{e} 6$ molecules $\mathrm{cm}^{-3}$ days), where the production of hydroxyacetone is dominated by secondary production via MAC.

Reconciliation of the mechanism of Peeters et al. (2009) with our observed OVOC ratios would require that the 1,5$\mathrm{H}$ and 1,6-H-shift decomposition reactions be as fast as the conventional reaction channels via $\mathrm{NO}$ and the reverse reaction rates of the Z-1-OH-4-OO* and Z-4-OH-1-OO* peroxyradicals be reduced. The implication is that the thermodynamic stability of these radicals would have to increase. Independent experimental evidence was recently presented by Paulot et al. (2009a), who tentatively concluded that much smaller yields for the (2Z)-hydroperoxymethylbutenal (e.g. $<10 \%)$ than would be predicted via the $1,6-\mathrm{H}$ shifts were needed to explain their observations. One consequence of these independent experimental results is that they suggest a lower $\mathrm{HO}_{\mathrm{x}}$ recycling efficiency. For the standard mechanism proposed by Peeters et al. (2009) we calculate a $\mathrm{HO}_{\mathrm{x}}$ yield of $0.67\left(0.64 \mathrm{HO}_{2}+0.03 \mathrm{OH}\right)$ for AMAZE-08 conditions. When adjusting reaction rates to match the AMAZE08 OVOC observations we calculate an overall $\mathrm{HO}_{\mathrm{x}}$ yield of $0.22\left(0.10 \mathrm{HO}_{2}+0.12 \mathrm{OH}\right)$, corresponding to approximately $33 \%$ of the original yield.

\subsubsection{Interpretation of $\mathrm{OH}$ reactivity measurements in isoprene dominated environments}

If generalized these findings also have implications for $\mathrm{OH}$ reactivity measurements (di Carlo et al., 2004; Sinha et al., 2008) conducted close to isoprene emission sources. $\mathrm{OH}$ is considered the main oxidant in the atmosphere and reacts with all VOCs. The reaction frequency of a VOC with $\mathrm{OH}$ is defined as the product of its rate-coefficient times its concentration. The sum of all reaction frequencies is the inverse of the $\mathrm{OH}$ lifetime and is termed $\mathrm{OH}$ reactivity. The measurement of $\mathrm{OH}$ reactivity has been used as a top-down constraint to infer VOC sources in the atmosphere (e.g. di Carlo et al., 2004; Sinha et al., 2008). However, since all reactive VOCs are not always measured concurrently, 


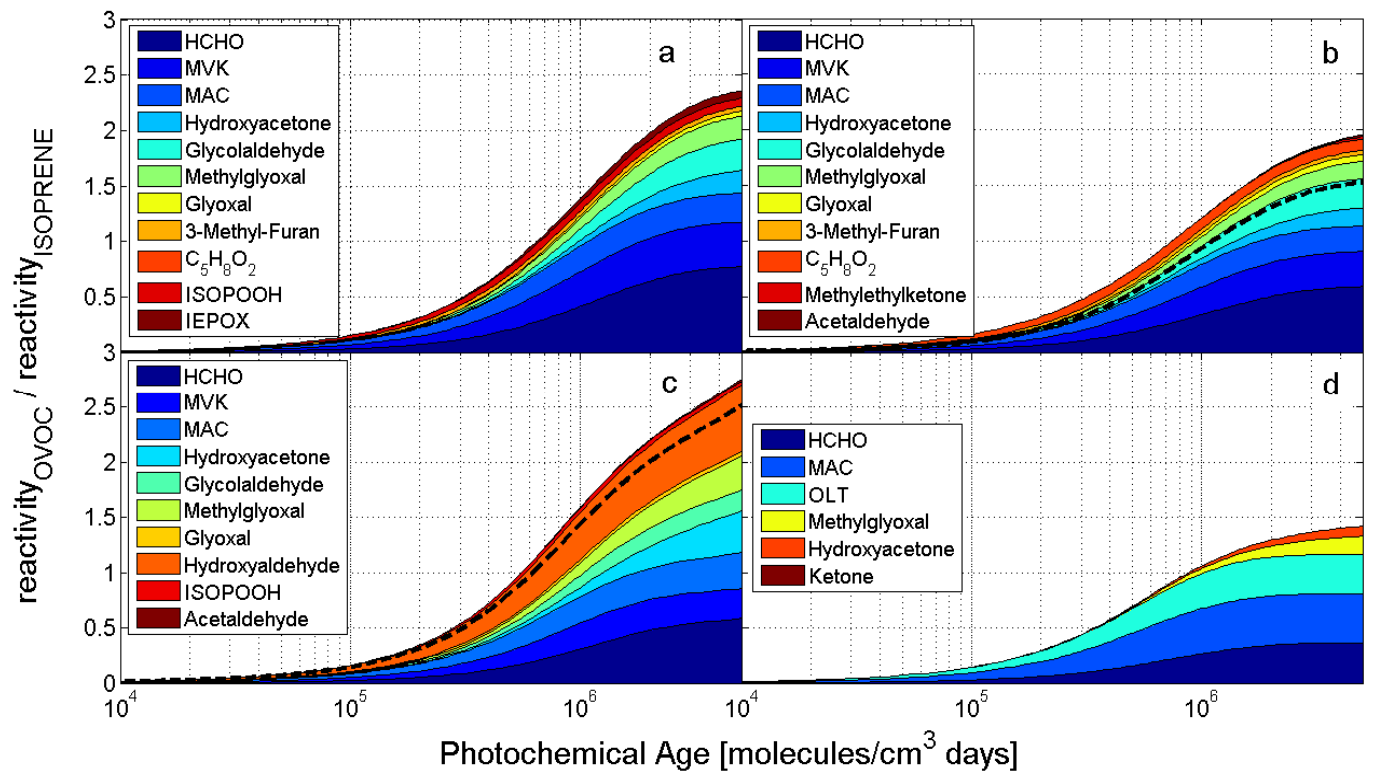

Fig. 6. Evolution of the $\mathrm{OH}$ reactivity of OVOC oxidation products relative to isoprene as a function of photochemical age calculated for four photochemical oxidation schemes. Panel (a): Paulot et al., 2009 a and b. Panel (b): sequential reaction model (SRM) including the fast production of OVOCs according to Table A2 (Appendix). The black dashed line shows the total reactivity without fast production of OVOCs. Panel (c): same for Mozart mechanism. Panel (d): RACM mechanism.

photochemical models must be used to estimate contributions of many species to the overall $\mathrm{OH}$ reactivity. Rapid formation of isoprene oxidation products could lead to a higher modelled $\mathrm{OH}$ reactivity than assumed based on current photo-oxidation mechanisms. This becomes particularly important when lumped chemical schemes are used (di Carlo et al., 2004), which further simplify the chemical degradation mechanism of VOCs.

In order to test the uncertainty of modelled $\mathrm{OH}$ reactivity, we compare four different oxidation schemes for the most prominent OVOCs produced from isoprene (Fig. 6). Figure 6a shows the evolution of OVOCs relative to isoprene inferred from the mechanism proposed by Paulot et al. (2009a, b). It includes the production of a newly discovered class of OVOCs (epoxides: IEPOX). For simplicity we have excluded the contribution from isoprene nitrates which contribute less than $2 \%$ for conditions encountered during AMAZE-08. Panel $b$ depicts the OVOC evolution based on an extensive set of reactions implemented in a kinetic reaction model (see Tables 1 and 2 Appendix). The black dashed line shows the evolution of the $\mathrm{OH}$ reactivity of isoprene oxidation products without the fast OVOC production channels. Panel c shows results obtained from the Mozart mechanism (Emmons et al., 2009). As in panel b the black dashed line shows the model run without fast production of OVOCs. Panel d depicts the formation of isoprene photo-oxidation products based on the Regional Atmospheric Chemistry Mechanism (RACM) (Stockwell et al.,
1997), which has previously been used to model OH reactivity for studies of missing OH sinks (di Carlo et al., 2004). Most of the reactivity in RACM is lumped into six species: formaldehyde, methacrolein, OLT (terminal alkenes, such as propene), methylglyoxal, hydroxyacetone and a generic ketone.

As discussed in Sect. 3.1 the influence of mixing is neglected because OVOC concentrations are assumed to be small in the FT compared to the PBL during daytime. This simplification results in a systematic overestimation of the OVOC reactivity, as they are longer-lived than isoprene and the concentration jump between the FT and the PBL would be smaller than for isoprene. Previous aircraft measurements have shown that MVK and MAC decrease rapidly in the FT similar to isoprene (Karl et al., 2007; Kuhn et al., 2007). Therefore the influence of vertical entrainment would likely impact the distribution on timescales longer than 5-6 h. For example for midday $\mathrm{OH}$ concentrations of $5 \mathrm{e} 6$ molecules $/ \mathrm{cm}^{3}$ vertical entrainment would mostly influence the reactivity distribution for photochemical ages greater than $1 \mathrm{e} 6$ molecules $/ \mathrm{cm}^{3}$ days.

For typical conditions during AMAZE-08 the modelled $\mathrm{OH}$ reactivity from photo-oxidation products could account for $20-150 \%$ of the measured reactivity relative to isoprene depending on the photochemical age. Formaldehyde (HCHO), an important intermediate isoprene oxidation product, can account for up to $30 \%$ of the OVOC reactivity. Together the major oxidation products MVK, MAC and $\mathrm{HCHO}$ 
typically account for up to $75 \%$ of the OVOC reactivity. Adding rapid formation of OVOCs to this scheme could increase the reactivity of photo-oxidation products relative to isoprene by up to $20 \%$ for the kinetic reaction model (e.g. dashed line panel b). For the longest photochemical age considered ( $5 \mathrm{e} 6$ molecules $/ \mathrm{cm}^{3}$ days) the maximum contribution of the OVOC reactivity relative to isoprene between the Paulot mechanism (panel a), the sequential reaction model (panel b) and the Mozart mechanism (panel c) falls between 2 and 2.7. The RACM mechanism would predict a ratio of 1.5. For shorter photochemical ages the range of modelled OVOC reactivities relative to isoprene is smaller. For a given (MVK+MAC)/isoprene ratio of 0.44 the contributions of the modelled OVOC reactivity ratios relative to isoprene are $0.21,0.25,0.27$ and 0.30 for the Paulot mechanism, the kinetic reaction model, the Mozart mechanism and the RACM mechanism respectively. The four schemes would then all lie within $4 \%$. The reactivity ratio calculated from the sequential reaction model without inclusion of fast OVOC production however would be $32 \%$ smaller (e.g. 0.17) than with fast OVOC production (0.25). The total contribution of OVOCs from the RACM model (e.g. without including the lumped hydrocarbon species OLT) is 0.20 and would be 5 to $35 \%$ smaller compared to the other three mechanisms. When constraining by photochemical age only, the RACM mechanism tends to underpredict the overall reactivity ratio relative to the other three schemes. As an example the overall reactivity ratio based on RACM would be $20 \%-30 \%$ lower compared to the Mozart mechanism for photochemical ages between $5 \mathrm{e} 5$ and $1 \mathrm{e} 6$ molecules $/ \mathrm{cm}^{3}$ days. Based on this analysis it could be as much as $\sim 30-50 \%$ lower than the OVOC reactivity from the three other mechanisms if solely based on an estimation of photochemical age.

The presented analysis suggests that a large fraction of the missing VOCs inferred from $\mathrm{OH}$ reactivity measurements in forested environments (e.g. 50\%) could be an overestimate associated with isoprene oxidation products not accounted for by lumped photo-chemical oxidation schemes. Given the fact that many OVOCs were typically not measured during previously reported discrepancies between modelled and measured OH reactivity (di Carlo et al., 2004; Sinha et al., 2008; Mao et al., 2009) the actual missing OH sink could be much smaller and perhaps reconciled without the need to invoke large missing sources of unknown primary biogenic VOCs. For modelled $\mathrm{OH}$ reactivities constrained by measured OVOC/isoprene ratios the relative variation between different photochemical oxidation schemes is much smaller (e.g. $4 \%$ for the four oxidation schemes investigated here). The slower evolution of OVOC reactivity in the RACM mechanism would then largely be compensated.

\section{Conclusion and summary}

Our field observations in the wet season of the central Amazon Basin show that the distribution of MVK and MAC produced from isoprene oxidation is largely consistent with our current understanding of their photochemical production routes. Three explicit schemes for MVK and MAC are able to reproduce these species reasonably well. However the relative ratios among hydroxyacetone, MVK and MAC suggest that the production of hydroxyacetone is faster than current chemical photo-oxidation mechanisms can explain. The discrepancy between observations and traditional chemical isoprene degradation schemes could be reconciled by introducing direct production from isoprene and very fast secondary production as has recently been proposed theoretically.

A newly proposed isoprene mechanism that recycles $\mathrm{HO}_{\mathrm{x}}$ is largely inconsistent with observed OVOC ratios unless the thermodynamic stability of certain isoprene peroxyradicals was larger than predicted by quantum mechanical calculations.

Our measurements demonstrate the importance of accurate representation of OVOCs, which act as an $\mathrm{OH}$ sink and precursors for secondary organic aerosols (SOA). To date only a few studies (Spaulding et al., 2003; Warneke et al., 2001) have reported field measurements of selected OVOCs produced from isoprene chemistry. A more extensive set of OVOC observations will be necessary to fully constrain $\mathrm{OH}$ reactivity measurements in the future and will help improve uncertainties associated with modelling $\mathrm{OH}$ lifetimes in isoprene dominated environments.

\section{Appendix A}

A sequential reaction model was used to calculate the evolution of prominent isoprene photo oxidation products. Table 1 lists compounds included in the present analysis. Due to poor understanding of atmospheric oxidation of some OVOCs the sequential reaction model was restricted to first, second and third generation products exhibiting $\mathrm{OH}$ reaction rate coefficients greater than $1 \mathrm{e}-12 \mathrm{~cm}^{3} / \mathrm{s}$. The selection was also based on the fact that the present analysis is restricted to photochemical ages of $<2 \mathrm{e} 6$ molecules $/ \mathrm{cm}^{3}$ days, typically encountered close to isoprene emission sources. In addition the evolution of OVOCs was calculated using two lumped chemistry schemes (Mozart Chem version 4, Pfister et al., 2009; and RACM, Stockwell et al., 1997). The Mozart Chemistry scheme is used in a global atmospheric chemistry model and includes nearly explicit representation of the first and second generation oxidation products from isoprene. The Regional Atmospheric Chemistry Mechanism (RACM) was originally developed for regional air quality purposes and exhibits a higher degree of lumping for isoprene products than the Mozart Chemistry scheme. 
Table A1. VOCs considered for the sequential reaction model.

\begin{tabular}{lrr}
\hline VOC & Rate Coefficient $(295 \mathrm{~K})$ & $\begin{array}{r}\text { Photolysis } \\
{\left[\mathrm{cm}^{3} / \mathrm{s}\right]}\end{array}$ \\
& $1.0 \mathrm{E}-10^{\mathrm{a}, \mathrm{b}}$ & - \\
\hline Isoprene (C5H8) & $1.9 \mathrm{E}-11^{\mathrm{a}, \mathrm{b}}$ & $1.2 \mathrm{E}-6$ \\
Methylvinylketone (MVK) & $3.4 \mathrm{E}-11^{\mathrm{a}, \mathrm{b}}$ & $2.2 \mathrm{E}-6$ \\
Methacrolein (MAC) & $6.0 \mathrm{E}-12^{\mathrm{c}}$ & $<1 \mathrm{E}-6$ \\
Hydroxyacetone (HYAC) & $1.1 \mathrm{E}-11^{\mathrm{d}}$ & $4 \mathrm{E}-6$ \\
Glycolaldehyde (GLYALD) & $1.7 \mathrm{E}-11^{\mathrm{a}}$ & $1 \mathrm{E}-4$ \\
Methylglyoxal (MeGLYO) & $1.2 \mathrm{E}-11^{\mathrm{a}}$ & $6 \mathrm{E}-5$ \\
Glyoxal (GLYO) & $1.0 \mathrm{E}-11^{\mathrm{a}}$ & $4 \mathrm{E}-5^{\mathrm{h}}$ \\
Formaldehyde (HCHO) & $9.3 \mathrm{E}-11^{\mathrm{a}}$ & - \\
$3-\mathrm{Methylfuran}_{\text {(MF) }}$ & $5.0 \mathrm{E}-11^{\mathrm{e}}$ & $<1 \mathrm{E}-6$ \\
$\mathrm{C}_{5} \mathrm{H}_{8} \mathrm{O}_{2}$ (e.g. 4-Hydroxy-2-methylbut-2enal) (HC5) & $1.3 \mathrm{E}-12^{\mathrm{f}}$ & $7 \mathrm{E}-7$ \\
Methylethylketone (MEK) & $1.4 \mathrm{E}-11^{\mathrm{f}}$ & $5 \mathrm{E}-6$ \\
Acetaldehyde (CH3CHO) & & \\
\hline
\end{tabular}

a Carter and Atkinson (1996)

b Gieczak et al. (1997)

${ }^{c}$ Dillon et al. (2006) (3 times larger rate constant than in Atkinson et al., 1997)

d Bacher et al. (2001)

e estimated based on Kwok et al. (1996)

${ }^{\mathrm{f}}$ Atkinson et al. (1997)

$\mathrm{g}$ from Tropospheric Ultraviolet and Visible (TUV) Radiation Model: http://cprm.acd.ucar.edu/Models/TUV/

$\mathrm{h}$ for molecular and radical branch

Table A2. Simplified sequential reaction model used to calculate OH reactivity based on VOCs listed in Table 1 assuming sufficiently high NO concentrations. Production of CO is not included. Mechanism is based on the Mozart mechanism v4 (Emmons, 2009) including additions proposed by Paulot et al. (2009b).

\begin{tabular}{|c|c|}
\hline Reaction: $\mathrm{VOC}+\mathrm{OH}$ & Products \\
\hline Isoprene (C5H8) & $\begin{array}{l}0.63 \mathrm{HCHO}+0.32 \mathrm{MVK}+0.23 \mathrm{MAC}+\mathrm{Y}_{\text {isoa }} \mathrm{HYAC}+\mathrm{Y}_{\text {isoa }} \\
\text { GLYALD+Y } \\
\text { isoa MeGLYO+Y isoa GLYO+Y }\end{array}$ \\
\hline Methylvinylketone (MVK) & 0.65 GLYALD+0.3 MeGLYO+0.3 HCHO \\
\hline Methacrolein (MAC) & $0.42 \mathrm{HYAC}+0.08 \mathrm{MeGLYO}+0.50 \mathrm{HCHO}$ \\
\hline Hydroxyacetone (HYAC) & $0.91 \mathrm{MeGLYO}+(0.125 \text { Acetic Acid })^{2}$ \\
\hline Glycolaldehyde (GLYALD) & $0.2 \mathrm{GLYO}+0.8 \mathrm{HCHO}$ \\
\hline $\mathrm{C}_{5} \mathrm{H}_{8} \mathrm{O}_{2}$ (e.g. 4-Hydroxy-2-methylbut-2enal) (HC5) & $0.5 \mathrm{MEK}+0.25$ GLYALD+0.25 MeGLYO \\
\hline Methylethylketone & $\mathrm{CH} 3 \mathrm{CHO}$ \\
\hline
\end{tabular}

${ }^{1} \mathrm{Y}_{\text {isoa }}=(0.083 \pm 0.022)$ : Yield based on estimated yields for hydroxyacetone. $\mathrm{Y}_{\text {isob }}=0.45 \times \mathrm{Y}_{\text {isoa }}$;

${ }^{2}$ Further photooxidation of acetic acid is neglected due to slow reaction rate. 
Table A3. Initial radical and peroxyradical reactions according to Peeters et al. (2009). The asterisk (*) symbol indicates an $\mathrm{R}$ or $\mathrm{RO}_{2}$ radical. Further reactions of MVK, MAC and hydroxyacetone are treated as a first order reaction with respect to $\mathrm{OH}$ according to Table 2. Only the $\mathrm{OH}$-addition to carbons 1 and 4 in isoprene are considered here correspoinding to $90 \%$ of oxidized carbon. This is reflected by the radical yields after initial $\mathrm{OH}$ addition. Reaction constants and rates used for the calculations are listed in the last column. The reaction rates $\mathrm{kf}$ and $\mathrm{kr}$ represent the forward and reverse reactions for $\mathrm{O}_{2}$ addition and elimination and the forward reactions for the 1,6 and 1,5-H-shifts.

\begin{tabular}{|c|c|c|}
\hline Reaction VOC & Products & $\mathrm{k}_{\mathrm{OH}}\left(\mathrm{cm}^{3} / \mathrm{s}\right)$ \\
\hline Isoprene $+\mathrm{OH}$ & 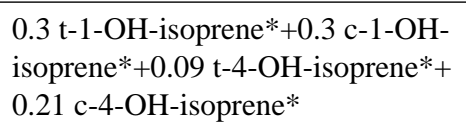 & $1.0 \mathrm{E}-10^{\mathrm{a}}$ \\
\hline $\mathrm{O}_{2}$ addition/elimination & & $\begin{array}{l}\mathrm{kf}\left(/ 10^{-12}\right) / \mathrm{kr} \\
\left(\mathrm{cm}^{3} / \mathrm{s}\right) /\left(\mathrm{s}^{-1}\right)^{\mathrm{b}}\end{array}$ \\
\hline $\mathrm{t}-1-\mathrm{OH}$-isoprene $*+\mathrm{O}_{2}$ & $\begin{array}{l}\text { E-1-OH-4-OO*-isoprene } \\
\text { 1-OH-2-OO*-isoprene }\end{array}$ & $\begin{array}{l}0.3 / 15.0 \\
15 / 7.0\end{array}$ \\
\hline c-1-OH-isoprene* $+\mathrm{O}_{2}$ & $\begin{array}{l}\text { 1-OH-2-OO*-isoprene } \\
\text { Z-1-OH-4-OO*-isoprene }\end{array}$ & $\begin{array}{l}1.5 / 2.1 \\
1.4 / 30.0\end{array}$ \\
\hline $\mathrm{t}$-4-OH-isoprene $*+\mathrm{O}_{2}$ & $\begin{array}{l}\text { E-4-OH-1-OO*-isoprene } \\
\text { 4-OH-3-OO*-isoprene }\end{array}$ & $\begin{array}{l}0.3 / 5.0 \\
1.5 / 1.6\end{array}$ \\
\hline c-4-OH-isoprene $*+\mathrm{O}_{2}$ & $\begin{array}{l}\text { 4-OH-3-OO*-isoprene } \\
\text { Z-4-OH-1-OO*-isoprene }\end{array}$ & $\begin{array}{l}1.5 / 1.9 \\
1.0 / 12.0\end{array}$ \\
\hline $\mathrm{RO}_{2}+\mathrm{NO}$ & & $\mathrm{k}_{\mathrm{NO}}\left(\mathrm{cm}^{3} / \mathrm{s}\right)^{\mathrm{c}}$ \\
\hline E-1-OH-4-OO*-isoprene & products & $8.0 \mathrm{E}-12$ \\
\hline 1-OH-2-OO*-isoprene & $0.93 \mathrm{MVK}$ & $8.0 \mathrm{E}-12$ \\
\hline Z-1-OH-4-OO*-isoprene & products & $8.0 \mathrm{E}-12$ \\
\hline E-4-OH-1-OO*-isoprene & Products & $8.0 \mathrm{E}-12$ \\
\hline 4-OH-3-OO*-isoprene & $0.93 \mathrm{MAC}$ & $8.0 \mathrm{E}-12$ \\
\hline Z-4-OH-1-OO*-isoprene & 0.5 hydroxyacetone & $8.0 \mathrm{E}-12$ \\
\hline $\mathrm{RO}_{2}+\mathrm{HO}_{2}$ & products & $8.0 \mathrm{E}-12$ \\
\hline $\mathrm{RO}_{2}+\mathrm{RO}_{2}$ & products & $8.0 \mathrm{E}-12$ \\
\hline $\mathrm{RO}_{2} \mathrm{H}$-shifts & & $\mathrm{kf}\left(\mathrm{s}^{-1}\right)^{\mathrm{b}}$ \\
\hline 1-OH-2-OO*-isoprene (1,5-H-shift) & $\mathrm{OH}+\mathrm{HCHO}+\mathrm{MVK}$ & $4.0 \mathrm{E}-03$ \\
\hline 4-OH-3-OO*-isoprene (1,5-H-shift) & $\mathrm{OH}+\mathrm{HCHO}+\mathrm{MAC}$ & $1.1 \mathrm{E}-02$ \\
\hline Z-1-OH-4-OO*-isoprene (1,6-H-shift) & $\mathrm{HO}_{2}+$ hydroperoxymethylbutenal & 1.0 \\
\hline Z-4-OH-1-OO*-isoprene (1,6-H-shift) & $\mathrm{HO}_{2}+$ hydroperoxymethylbutenal & 8.0 \\
\hline
\end{tabular}

a Carter and Atkinson (1996); Gieczak et al. (1997)

b Peeters et al. (2009)

c Emmons et al. (2009) 
Acknowledgements. The authors thank the entire AMAZE-08 team for their excellent support and vital collaboration. We also thank Paul Wennberg, Fabien Paulot, John Orlando and an anonymous reviewer for their constructive comments. The National Center for Atmospheric Research is operated by the University Corporation for Atmospheric Research under sponsorship from the National Science Foundation.

Edited by: R. Cohen

\section{References}

Atkinson, R.: Atmospheric chemistry of VOCs and $\mathrm{NO}_{\mathrm{x}}$, Atmos. Environ., 34, 2063-2101, 2000.

Atkinson, R., Baulch, D. L., Cox, R. A., Hampson Jr., R. F., Kerr, J. A., Rossi, M. J., and Troe, J.: Evaluated kinetic, photochemical and heterogeneous data for atmospheric chemistry: supplement V, IUPAC subcommittee on gas kinetic data evaluation for atmospheric chemistry, J. Phys. Chem. Ref. Data, 26, 521-1011, 1997.

Bacher, C., Tyndall, G. S., and Orlando, J. J.: The atmospheric chemistry of glycolaldehyde, J. Atmos. Chem., 39(2), 171-189, 2001.

Bey, I., Jacob, D. J., Yantosca, R. M., Logan, J. A., Field, B., Fiore, A. M., Li, Q., Liu, H., Mickley, L. J., and Schultz, M.: Global modeling of tropospheric chemistry with assimilated meteorology: Model description and evaluation, J. Geophys. Res., 106, 23073-23096, 2001.

Brasseur, G. P., Hauglustaine, D. A., Walters, S., Rasch, P. J., Muller, J.-F., Granier, C., and Tie, X.-X.: MOZART, A global chemical transport model for ozone and related chemical tracers, Part 1: Model description, J. Geophys. Res., 103, 28265-28289, 1998.

Carter, W. P. L. and Atkinson, R.: Development and evaluation of a detailed mechanism for atmospheric reactions of isoprene and $\mathrm{NO}_{\mathrm{x}}$, Int. J. Chem. Kinet., 28, 497-530, 1996.

Carlo, P. D., Brune, W. H., Martinez, M., Harder, H., Lesher, R., Ren, X., Thornberry, T., Carroll, M. A., Young, V., Shepson, P. B., Riemer, D., Apel, E., and Campbell, C.: Missing OH reactivity in a forest: evidence for unkown reactive biogenic VOCs, Science, 304, 722-725, 2004.

Claeys, M., Graham, B., Vas, G., Wang, W., Vermeylen, R., Pashynska, V., Cafmeyer, J., Guyon, P., Andreae, M. O., Artaxo, P., and Maenhaut, W.: Formation of secondary organic aerosols through photooxidation of isoprene, Science, 303, 1173-1176, 2004,.

Dibble, T. S.: Prompt chemistry of alkenoxy radical products of the double $\mathrm{H}$-atom transfer of alkoxy radicals from isoprene, J. Phys. Chem. A., 108, 2208-2215, 2004.

Dillon, T. J., Horowitz, A., Holscher, D., Crowley, J. N., Vereecken, L., and Peeters, J.: Reaction of $\mathrm{HO}$ wfth hydroxyacetone (HOCH2C(O)CH3): rate coefficients $(233-363 \mathrm{~K})$ and mechanism, Phys. Chem. Chem. Phys., 8, 236-246, 2006.

de Gouw, J. and Warneke, C.: Measurements of volatile organic compounds in the earths atmosphere using proton-transferreaction mass spectrometry, Mass Spectrom. Rev., 26, 223-257, 2007.

Emmerson, K. M. and Evans, M. J.: Comparison of tropospheric gas-phase chemistry schemes for use within global models, At- mos. Chem. Phys., 9, 1831-1845, 2009,

http://www.atmos-chem-phys.net/9/1831/2009/.

Emmons, L. K., Walters, S., Hess, P. G., Lamarque, J. F., Pfister, G. G., Fillmore, D., Granier, C., Guenther, A., Kinnison, D., Laepple, T., Orlando, J., Tie, X., Tyndall, G., Wiedinmyer, C., Baguhcum, S. L., and Kloster, S.: Description and evaluation of the Model for Ozone and Related chemical Tracers, version 4 (Mozart-4), Geosci. Model Dev. Discuss., 2, 1-57, 2009.

Eerdekens, G., Ganzeveld, L., Vilà-Guerau de Arellano, J., Klüpfel, T., Sinha, V., Yassaa, N., Williams, J., Harder, H., Kubistin, D., Martinez, M., and Lelieveld, J.: Flux estimates of isoprene, methanol and acetone from airborne PTR-MS measurements over the tropical rainforest during the GABRIEL 2005 campaign, Atmos. Chem. Phys., 9, 4207-4227, 2009,

http://www.atmos-chem-phys.net/9/4207/2009/.

Fan, J. and Zhang, R.: Atmospheric oxidation mechanism of isoprene, Environ. Chem., 1, 140-149, 2004.

Ganzeveld, L., Eerdekens, G., Feig, G., Fischer, H., Harder, H., Kónigstedt, R., Kubistin, D., Martinez, M., Meixner, F. X., Scheeren, H. A., Sinha, V., Taraborrelli, D., Williams, J., VilàGuerau de Arellano, J., and Lelieveld, J.: Surface and boundary layer exchanges of volatile organic compounds, nitrogen oxides and ozone during the GABRIEL campaign, Atmos. Chem. Phys., 8, 6223-6243, 2008,

http://www.atmos-chem-phys.net/8/6223/2008/.

Greenberg, J. P. and Zimmerman, P. R.: Nonmethane hydrocarbons in remote tropical, continental, and marine atmospheres, J. Geophys. Res., 89(ND3), 4767-4778, 1984.

Gierczak, T., Burkholder, J. B., Talukdar, R. K., Mellouki, A., Barone, S. B., and Ravishankara, A. R.: Atmospheric fate of methyl vinyl ketone and methacrolein, J. Photoch. Photobio. A, 110, 1-10, 1997.

Greenberg, J. P. and Zimmerman, P. R.: Nonmethane hydrocarbons in remote tropical, continental, and marine atmospheres, J. Geophys. Res., 89, 4767-4778, 1984.

Greenberg, J., Lee, B., Helmig, D., and Zimmerman, P.: Fully automated gas chromatograph-flame ionization detector system for the in situ determination of atmospheric non-methane hydrocarbons at low parts per trillion concentration, J. Chromatogr., 676, 389-398,1994.

Guenther, A., Karl, T., Harley, P., Wiedinmyer, C., Palmer, P. I., and Geron, C.: Estimates of global terrestrial isoprene emissions using MEGAN (Model of Emissions of Gases and Aerosols from Nature), Atmos. Chem. Phys., 6, 3181-3210, 2006, http://www.atmos-chem-phys.net/6/3181/2006/.

Hansel, A., Jordan, A., Warneke, C., Holzinger, R., and Lindinger, W.: Improved detection limit of the proton-transfer reaction mass spectrometer: on-line monitoring of volatile organic compounds at mixing ratios of a few pptv, Rapid Commun. Mass Sp., 12, 871-875, 1998.

Hofzumahaus, A., Rohrer, F., Lu, K. D., Bohn, B., Brauers, T., Chang, C. C., Fuchs, H., Holland, F., Kita, K., Kondo, Y., Li, X., Lou, S. R., Shao, M., Zeng, L. M., Wahner, A., and Zhang, Y. H.: Amplified Trace Gas Removal in the Troposphere, Science, 324, 1702-1704, 2009.

Holland, P. W. and Welsh, R. E.: Robust regression using iteratively reweighted least-squares, Commun. Stat. A-Theor., 6, 813-827, 1977.

Holzinger, R., Millet, D. B., Williams, B., Lee, A., Kreisberg, N., 
Hering, S. V., Jimenez, J., Allan, J. D., Worsnop, D. R., and Goldstein, A. H.: Emission, oxidation, and secondary organic aerosol formation of volatile organic compounds as observed at Chebogue Point, Nova Scotia, J. Geophys. Res., 112, D10S24, doi:10.1029/2006JD007599, 2007.

Kanakidou, M., Seinfeld, J. H., Pandis, S. N., Barnes, I., Dentener, F. J., Facchini, M. C., Van Dingenen, R., Ervens, B., Nenes, A., Nielsen, C. J., Swietlicki, E., Putaud, J. P., Balkanski, Y., Fuzzi, S., Horth, J., Moortgat, G. K., Winterhalter, R., Myhre, C. E. L., Tsigaridis, K., Vignati, E., Stephanou, E. G., and Wilson, J.: Organic aerosol and global climate modelling: a review, Atmos. Chem. Phys., 5, 1053-1123, 2005, http://www.atmos-chem-phys.net/5/1053/2005/.

Karl, T., Potosnak, M., Guenther, A., Clark, D., Walker, J., Herrick, J. D., and Geron, C.: Exchange processes of volatile organic compounds above a tropical rain forest: Implications for modeling tropospheric chemistry above dense vegetation, J. Geophys. Res., 109, D18306, doi:10.1029/2004JD004738, 2004.

Karl, T., Guenther, A., Yokelson, R. J., Greenberg, J., Potosnak, M., Blake, D. R., and Artaxo, P.: The tropical forest and fire emissions experiment: Emission, chemistry, and transport of biogenic volatile organic compounds in the lower atmosphere over Amazonia, J. Geophys. Res., 112, D18302, doi:10.129/2007JD008539, 2007.

Karl, T. G., Christian, T. J., Yokelson, R. J., Artaxo, P., Hao, W. M., and Guenther, A.: The Tropical Forest and Fire Emissions Experiment: method evaluation of volatile organic compound emissions measured by PTR-MS, FTIR, and GC from tropical biomass burning, Atmos. Chem. Phys., 7, 5883-5897, 2007, http://www.atmos-chem-phys.net/7/5883/2007/.

Kesselmeier, J., Ciccioli, P., Kuhn, U., Stefani, P., Biesenthal, T., Rottenberger, S., Wolf, A., Vitullo, M., Valentini, R., Nobre, A., Kabat, P., and Andreae, M. O.: Volatile organic compound emissions in relation to plant carbon fixation and the terrestrial carbon budget, Global Biogeochem. Cy., 16, 1126, doi:10.1029/2001GB001813, 2002.

Kroll, J. H., Ng, N. L., Murphy, S. M., Flagan, R. C., and Seinfeld, J. H.: Secondary organic aerosol formation from isoprene photooxidation, Environ. Sci. Technol., 40, 1869-1877, 2006.

Kuhn, U., Andreae, M. O., Ammann, C., Araújo, A. C., Brancaleoni, E., Ciccioli, P., Dindorf, T., Frattoni, M., Gatti, L. V., Ganzeveld, L., Kruijt, B., Lelieveld, J., Lloyd, J., Meixner, F. X., Nobre, A. D., Pöschl, U., Spirig, C., Stefani, P., Thielmann, A., Valentini, R., and Kesselmeier, J.: Isoprene and monoterpene fluxes from Central Amazonian rainforest inferred from towerbased and airborne measurements, and implications on the atmospheric chemistry and the local carbon budget, Atmos. Chem. Phys., 7, 2855-2879, 2007,

http://www.atmos-chem-phys.net/7/2855/2007/.

Kwok, E. S. C., Aschmann, S. M., and Atkinson, R.: Rate constants for the gas-phase reaction of selected carbamates and lactates, Environ. Sci. Technol., 30, 329-334, 1996.

Lelieveld, J., Butler, T. M., Crowley, J. N., Dillon, T. J., Fischer,H., Ganzeveld, L., Harder, H., Lawrence, M. G., Martinez, M., Taraborrelli, D., and Williams, J.: Atmospheric oxidation capacity sustained by a tropical forest, Nature, 452, 737-740, 2008.

Lindinger, W., Jordan, A., and Hansel, A.: Proton-transfer-reaction mass spectroscopy (PTR-MS): on-line monitoring of volatile organic compounds at pptv levels, Chem. Soc. Rev., 27, 347-534,
1998.

Nemitz, E., Sutton, M. A., Gut, A., Jose, R. S., Husted, S., and Schjoerring, J. K.: Sources and sinks of ammonia within an oilseed rape canopy, Agr. For. Meteorol., 105, 385-404, 2000.

Park, J., Candice, G. J., Zhang, R., and North, S. W.: Cyclization reactions in isoprene derived $\beta$-hydroxy radicals: implications for the atmospheric oxidation mechanism, Phys. Chem. Chem. Phys., 5, 3638-3642, 2003.

Peeters, J., Nguyen, T. L., and Vereecken, L.: $\mathrm{HO}_{\mathrm{x}}$ radical regeneration in the oxidation of isoprene, Phys. Chem. Chem. Phys., 11, 5935-5939, 2009.

Paulot, F., Crounse, J. D., Kjaergaard, H. G., Kurten, A., St. Clair, J. M., Seinfeld, J. H., and Wennberg, P. O.: Unexpected epoxide formation in the gas-phase photooxidation of isoprene, Science, 325, 730-733, 2009a.

Paulot, F., Crounse, J. D., Kjaergaard, H. G., Kroll, J. H., Seinfeld, J. H., and Wennberg, P. O.: Isoprene photooxidation: new insights into the production of acids and organic nitrates, Atmos. Chem. Phys., 9, 1479-1501, 2009b,

http://www.atmos-chem-phys.net/9/1479/2009/.

Pinho, P. G., Pio, C. A., and Jenkin, M. E.: Evaluation of isoprene degradation in the detailed tropospheric chemical mechanism, MCM v3, using environmental chamber data, Atmos. Environ., 39, 1303-1322, 2005.

Raupach, M. R.: A practical Lagrangian method for relating scalar concentrations to source distributions in vegetation canopies, Q. J. Roy. Meteorol. Soc., 115, 609-632, 1989.

Seber, G. A. F. and Wild, C. J.: Nonlinear Regression, John Wiley \& Sons Inc., 1989.

Sinha, V., Williams, J., Crowley, J. N., and Lelieveld, J.: The Comparative Reactivity Method - a new tool to measure total $\mathrm{OH}$ Reactivity in ambient air, Atmos. Chem. Phys., 8, 2213-2227, 2008, http://www.atmos-chem-phys.net/8/2213/2008/.

Spaulding, R. S., Schade, G. W., Goldstein, A. H., and Charles, M. J.: Characterization of secondary atmospheric photooxidation products: Evidence for biogenic and anthropogenic sources, J. Geophys. Res., 108, D84247, doi:10.1029/2002JD002478, 2003.

Stockwell, W. R., Kirchner, F., Kuhn, M., and Seefeld, S.: A new mechanism for regional atmospheric chemistry modeling, J. Geophys. Res., 102, 25847-25879, 1997.

Stroud, C., Roberts, J. M., Goldan, P. D., Kuster, W. C., Murphy, P. C., Williams, E. J., Hereid, D., Parrish, D., Sueper, D., Trainer, M., Fehsenfeld, F. C., Apel, E. C., Riemer, D., Wert, B., Henry, B., Fried, A., Martinez-Harder, M., Harder, H., Brune, W. H., Li, G., Xie, H., and Young, V. L.: Isoprene and its oxidation products, methacrolein and methylvinyl ketone, at an urban forested site during the 1999 Southern Oxidants Study, J. Geophys. Res., 106, 8035-8046, 2001.

Stroud, C., Makar, P., Karl, T., Guenther, A., Geron, C., Turnipseed, A., Nemitz, E., Baker, B., Potosnak, M., and Fuentes, J. D.: Role of canopy-scale photochemistry in modifying biogenicatmosphere exchange of reactive terpene species: Results from the CELTIC field study, J. Geophys. Res., 110, D17303, doi:10.1029/2005JD005775, 2005.

Taraborrelli, D., Lawrence, M. G., Butler, T. M., Sander, R., and Lelieveld, J.: Mainz Isoprene Mechanism 2 (MIM2): an isoprene oxidation mechanism for regional and global atmospheric modelling, Atmos. Chem. Phys., 9, 2751-2777, 2009, http://www.atmos-chem-phys.net/9/2751/2009/. 
von Kuhlmann, R., Lawrence, M. G., Pöschl, U., and Crutzen, P. J.: Sensitivities in global scale modeling of isoprene, Atmos. Chem. Phys., 4, 1-17, 2004, http://www.atmos-chem-phys.net/4/1/2004/.

Warneke, C., Holzinger, R., Hansel, A., Jordan, A., Lindinger, W., Poeschl, U., Williams, J., Hoor, P., Fischer, H., Crutzen, P. J., Scheeren, H. A., and Lelieveld, J.: Isoprene and its oxidation products methyl vinyl ketone, methacrolein, and isoprene related peroxides measured online over the 5 tropical rain forest of Surinam in March 1998, J. Atmos. Chem., 38, 167-185, 2001.

Williams, J., Poeschl, U., Crutzen, P. J., Hansel, A., Holzinger, R.,
Warneke, C., Lindinger, W., and Lelieveld, J.: An atmospheric chemistry interpretation of mass scans obtained from a proton transfer mass spectrometer flown over the tropical rainforest of Surinam, J. Atmos. Chem., 38, 133-166, 2001.

Yokelson, R. J., Karl, T., Artaxo, P., Blake, D. R., Christian, T. J., Griffith, D. W. T., Guenther, A., and Hao, W. M.: The Tropical Forest and Fire Emissions Experiment: overview and airborne fire emission factor measurements, Atmos. Chem. Phys., 7, 5175-5196, 2007,

http://www.atmos-chem-phys.net/7/5175/2007/. 